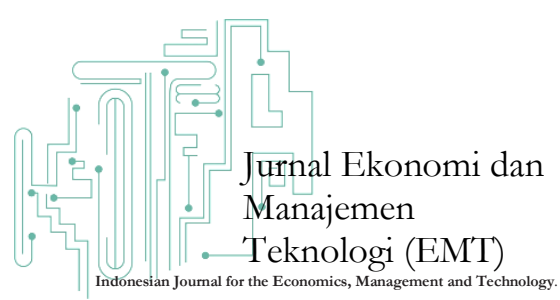

Jurnal Ekonomi dan Manajemen Teknologi, $3(2), 2019,81-84$

Available online at http://journal.lembagakita.org

\title{
Faktor-Faktor yang mempengaruhi Minat Wakaf Masyarakat di Kota Lhokseumawe
}

\author{
Falahuddin ${ }^{1}$, Fuadi ${ }^{2}$, M. Rizki Ramadhan ${ }^{3}$ \\ 1,2,3 Fakultas Ekonomi dan Bisnis Universitas Malikussaleh
}

\begin{abstract}
Abstrak. Penelitian ini bertujuan untuk mengetahui faktor-faktor yang mempengarubi Minat Wakaf masyarakat di Kota Lhokseumawe. Data yang digunakan adalah data primer dengan sampel 100 responden. Metode analisis data menggunakan regresi linier berganda dengan metode OLS (Ordinary Least Square). Hasil penelitian menunjukkan bahwa pengetahuan agama masyarakat berpengaruh positif dan tidak signifikan terhadap minat wakaf di Lhokseumawe. Persepsi Wakaf berpengarub positif dan tidak signifikan terhadap Minat Wakaf masyarakat di Kota Lhokseumawe, dan Pendapatan berpengarub positif dan tidak signifikan terhadap Minat Masyarakat Wakaf di Kota Lhokseumawe. Hasil uji determinasi yang digunakan adalah $4 \%$.
\end{abstract}

Kata kunci: Minat Waqaf, Pengetabuan agama, persepsi, pendapatan.

Abstract. This research is to find out the factors that influence the community Waqf Interest in Lhokseumawe City. The data used are primary data with a sample of 100 respondents. The data analysis method uses multiple linear regression with OLS (Ordinary Least Square) method. The results showed that community religious knowledge had a positive and not significant effect on waqf interest in Lhokseumawe. Perception of Waqf has a positive and insignificant effect on community Waqf Interest in Lhokseumawe City, and Revenue has a positive and insignificant effect on Waaf Community Interest in Lhokseumawe City. The determination test results used were $4 \%$.

Keywords: Wakaf Interests, Religiosity Knowledge, Wakif Perception, Income. 


\section{Pendahuluan}

Islam menghendaki agar manusia hidup dalam keadaan yang baik, hidup dengan mendapatkan keberkahan dari langit dan bumi, merasakan kebahagiaan karena terpenuhinya kebutuhan hidup, dan hati serta perasaannya merasa aman dengan nikmat Allah SWT yang memenuhi kebutuhan diri dan kehidupannya (Prastiawati \& Satya Darma, 2016). Islam sungguh mencintai manusia hidup bahagia dengan kekayaannya, sebaliknya membenci hidup manusia sengsara dengan kefakiran Islam telah menjadikan pemenuhan kebutuhan materi sebagai salah satu unsur penting dalam merealisasikan hidup bahagia (Prastiawati \& Satya Darma, 2016). Hal ini dapat diartikan bahwa Islam sangat menganjurkan umat untuk hidup berkecukupan agar dapat mencapai kebahagian dan dapat berbagi kepada orang lain sebagai manifestasi rasa syukur terhadap segala sesuatu yang sudah diberikan oleh Allah SWT (Hazami, 2016).

Salah satu dari bentuk ibadah untuk mendekatkan diri pada Allah SWT yang berkaitan dengan harta benda adalah wakaf (Hazami, 2016; Nurbismi \& Ramli, 2018). Amalan wakaf sangat besar artinya bagi kehidupan sosial ekonomi, kebudayaan dan keagamaan (Rachman \& Herianingrum, 2017). Oleh karena itu, Islam meletakkan amalan wakaf sebagai salah satu macam ibadah yang amat digembirakan (Abrar \& Hermawati, 2017). Wakaf merupakan salah satu instrumen dalam Islam untuk mencapai tujuan ekonomi Islam yaitu mewujudkan kehidupan yang sejahtera $(\mathrm{Al}$ Arif, 2012). Negara-negara berpenduduk muslim seperti Mesir, Saudi Arabia, Yordania, Turki, Bangladesh, Mesir, Malaysia dan Amerika Serikat, mengembangkan serta menerapkan wakaf sebagai salah instrumen untuk membantu berbagai kegiatan umat dan mengatasi masalah umat seperti kemiskinan (Ryandono \& Hazami, 2016; Ali, 2019).

Fenomena yang terjadi pada masyarakat mereka mengetahui tentang pahala yang didapat terhadap wakaf dan juga bisa memberi kenikmatan atau kepuasan terhadap persepsi wakif akan ketaatan kepada allah bagi wakif. Pendapatan juga berpengaruh terhadap minat wakaf. Di kota lhokseumawe banyak yang mewakafkan uang untuk pembangunan mesjid. Masyarakat yang berpendapatan tinggi setiap bulannya yang mewakafkan hartanya di jalan Allah. Preliminary survey melalui tanya jawab terhadap responden yang penulis yakini telah berwakaf uang untuk pembangunan mesjid. Minat wakaf masyarakat cenderung menurun, hanya sebagian masyarakat yang memiliki sedikit pendapatan yang berminat untuk wakaf. Wakaf masyarakat banyak untuk pembangunan mesjid. Untuk itu, hubungan pengetahuan kereligiusitas, persepsi wakif, dan pendapatan sangat mempengaruhi minat wakaf masyarakat. Untuk itu, masyarakat sekarang cenderung menimbun kekayaan tanpa memikirkan masa depan di akhirat nanti. Pengetahuan tentang pahala yang didapatkan dalam mengwakafkan harta di jalan allah sangat diperlukan dalam situasi saat ini. Wakaf merupakan sebuah amalan yang bisa menjadi sosial masyarakat di sekitarnya yaitu bermanfaat untuk masyarakat sekitar dan juga menjadi amalan jariah untuk masa depan di akhirat nanti.

\section{Literature Review}

\section{Minat Wakaf}

Alasan minat wakaf menjadi sebuah teori yaitu untuk menggiatkan masyarakat dalam setiap kegiatan maupun berwakaf diperlukan minat yang nantinya masyarakat berwakaf (Hidayatur, 2018). Minat merupakan kecenderungan seseorang untuk menentukan pilihan aktivitas. Pengaruh kondisi individual dapat merubah minat seseorang. Minat dipengaruhi oleh kecenderungan atau motivasi akan suatu gairah terhadap keinginan. Sedangkan secara etimologi pengertian minat adalah perhatian.

\section{Pendapatan}

Pendapatan juga menjadi sebuah alasan orang berwakaf (Nizar, 2014). jika pendapatan seseorang tidak melebihi akan suatu kebutuhan sehari-hari minat untuk berwakaf tidak menjadi sebuah tujuan. Apabila pendapatan melebihi dari kebutuhan sehari-hari minat untuk berwakaf akan menjadi sebuah tujuan dalam berwakaf di jalan allah swt. Pendapatan ialah tambahan harta yang diperoleh dari sumber yang diketahui dan bersifat tetap. Sumber pendapatan dapat bersifat material, seperti tanah atau non material seperti pekerjaan atau bisa dari keduanya. Sehingga pendapatan terbagi atas penghasilan, gaji/upah 
dan keuntungan. Islam telah menganjurkan berwakaf atas kekayaan juga mensunahkan shodaqah, infaq dan juga wakaf uang atas pendapatan.

\section{Hubungan Pendapatan terbadap Minat Wakaf}

Secara umum perilaku menabung maupun berwakaf setiap orang ditentukan oleh dua faktor keputusan penting (Wiliasih \& Shadrina, 2017). Pertama adalah merujuk pada seberapa besar pendapatan riil yang diterima akan dimanfaatkan untuk keperluan konsumsi. Kedua adalah merujuk pada seberapa besar pendapatan riil yang diterima akan disisihkan untuk ditabung (Murwanti \& Sholahuddin, 2013).

\section{Hipotesis}

Berdasarkan data empiris diatas maka dapat diajukan hipotesis adalah sebagai berikut :

H1 : Diduga Pengetahuan kereligiusitas berpengaruh terhadap minat wakaf di Kota Lhokseumawe.

H2 : Diduga Persepsi Wakaf berpengaruh terhadap minat wakaf di Kota Lhokseumawe.

H3 : Diduga Pendapatan berpengaruh terhadap minat wakaf di Kota Lhokseumawe..

\section{Metodologi Penelitian}

\section{Objek dan Lokasi Penelitian}

Objek yang menjadi penelitian penulis yaitu Pengetahuan Kereligiusitas Masyarakat, Persepsi Wakif, Pendapatan dan Minat Wakaf. Dalam melaksanakan penelitian ini penulis mengambil lokasi penelitian di Kota Lhokseumawe terhadap Masyarakat yang mengwakafkan hartanya.

\section{Populasi dan Sampel}

Populasi adalah jumlah kesuluruhan dari unit atau objek analisa yang ciri-ciri karakteristiknya hendak diduga (Hazami, 2016). Populasi penelitian ini adalah jumlah Jamaah Haji Kota Lhokseumawe Pada tahun 2017 yang berjumlah 222 jamaah haji. Kecamatan Banda Sakti sebanyak 122 orang, Kecamatan Muara Satu sebanyak 38 orang, Kecamatan Muara Dua sebanyak 42 orang, dan Kecamatan Blang Mangat 20 orang.

\section{Teknis Analisis}

Analisis data menggunakan regresi linier berganda, adapun metode yang dapat digunakan untuk mengestimasi parameter model regresi linier sederhana maupun model regresi linier berganda adalah dengan metode kuadrat terkecil (ordinary least square/OLS) dan metode. Analisis regresi linear multiples atau berganda berfungsi untuk mencari pengaruh dari dua atau lebih variabel independent (variabel bebas atau $\mathrm{X}$ ) terhadap variabel dependent (variabel terikat atau $\mathrm{Y})$, Adapun rumus persamaan analisis regresi multiples adalah sebagai berikut:

$$
\mathrm{Y}=\mathrm{a}+\mathrm{b} 1 \mathrm{x} 1+\mathrm{b} 2 \mathrm{x} 2 \ldots \mathrm{bn}
$$

\section{Hasil dan Pembahasan}

Berdasarkan Hasil Pengolahan Data di atas apabila diuraikan dalam model penelitian, maka persamaan model regresi linear berganda adalah sebagai berikut:

$$
\mathrm{Y}=8,81+0,01 \mathrm{X} 1+0,21 \mathrm{X} 2+1,85 \mathrm{X} 3+\mathrm{e}
$$

Variabel Pengetahuan Kereligiusitas berpengaruh positif terhadap Minat Wakaf sebesar 0,01 yang artinya apabila perubahan Pengetahuan Kereligiusitas meningkat 1 satuan maka perubahan Pendapatan akan naik sebesar 0,01 . Hasil penelitian juga menggambarkan bahwa variabel Persepsi Wakif berpengaruh positif terhadap Minat Wakaf sebesar 0,21 yang artinya apabila perubahan Persepsi Wakif meningkat 1 satuan maka perubahan Minat Wakaf akan naik sebesar 0,21. Variabel Pendapatan berpengaruh positif terhadap Minat Wakaf sebesar Rp.1.850 yang artinya apabila perubahan Pendapatan meningkat RP.1000 maka perubahan Minat Wakaf akan naik sebesar Rp.1.850.

\begin{tabular}{lrlll}
$\begin{array}{l}\text { Dependent Variable: } \\
\text { Method: Least Squares } \\
\text { Date: } 12 / 13 / 17 \text { Time: } 20: 15 \\
\text { Sample: } 1100 \\
\text { Included observations: } 100\end{array}$ & & & & \\
\hline \hline Variable & Coefficient & Std. Error & t-Statistic & Prob. \\
\hline C & 8.813900 & 1.761408 & 5.003894 & 0.0000 \\
X1 & 0.009633 & 0.124382 & 0.077448 & 0.9384 \\
X2 & 0.207544 & 0.122019 & 1.700921 & 0.0922 \\
X3 & $1.85 E-08$ & $8.27 E-08$ & 0.223752 & 0.8234 \\
\hline \hline R-squared & 0.040663 & Mean dependent var & 11.91000 \\
Adjusted R-squared & 0.010684 & S.D. dependent var & 1.272038 \\
S.E. of regression & 1.265225 & Akaike info criterion & 3.347555 \\
Sum squared resid & 153.6762 & Schwarz criterion & 3.451762 \\
Log likelihood & -163.3777 & Hannan-Quinn criter. & 3.389729 \\
F-statistic & 1.356365 & Durbin-Watson stat & 1.016496 \\
Prob(F-statistic) & 0.260837 & & & \\
\hline \hline
\end{tabular}

Gambar 1. Hasil Uji Model Analisis 


\section{Kesimpulan dan Saran}

\section{Kesimpulan}

1. Pengetahuan Kereligiusitas berpengaruh positif dan tidak signifikan terhadap Minat Wakaf di Kota Lhokseumawe.

2. Persepsi Wakif berpengaruh positif dan tidak signifikan terhadap Minat Wakaf di Kota Lhokseumawe.

3. Pendapatan berpengaruh positif dan tidak signifikan terhadap Minat Wakaf di Kota Lhokseumawe.

\section{Saran}

1. Sosialisasi tentang waqaf kepada seluruh masyarakat perlu lebih ditingkatkan, mengingat pemahaman warga masih minim. Pemerintah daerah dengan Masyarakat dapat memperoleh informasi dalam meningkatkan minat wakaf di kota Lhokseumawe.

2. Pemerintah daerah sampai ke tingakat desa dapat difungsikan untuk efesiensi sosialisasi ini.

\section{Daftar Pustaka}

Abrar, A., \& Hermawati, H. (2017). Implementasi Pengelolaan Tanah Wakaf Di Rumah Asuh Dompet Amal Sejahtera Ibnu Abbas (Dasi) NTB. TAFAQQUH: Jurnal Hukum Ekonomi Syariah Dan Ahwal Syahsiyah, 2(1), 28-46.

Al Arif, M. N. R. (2012). Wakaf uang dan pengaruhnya terhadap program pengentasan kemiskinan di Indonesia. Jurnal Indo-Islamika, 2(1), 17-29.

Ali, A. S. (2019). ANALISIS PENGELOLAAN HARTA WAQAF DI KOTA BANDA ACEH. AKBIS (Media Riset Akuntansi dan Bisnis), 3(2).

Hazami, B. (2016). Peran dan Aplikasi Wakaf dalam Mewujudkan Kesejahteraan Umat di Indonesia. Analisis, XVI(1), 173-204.
Hidayatur, R. (2018). pengaruh strategi penggalangan wakaf tunai dan religiusitas terhadap minat masyarakat untuk berwakaf pada pengelolaan wakaf ranting muhammadiyah kertosari kabupaten ponorogo tahun 2018 (Doctoral dissertation, IAIN Ponorogo).

Murwanti, S., \& Sholahuddin, M. (2013). Peran Keuangan Lembaga Mikro Syariah untuk Usaha Mikro di Wonogiri. Call Paper Sancall, 300-309.

Nizar, A. (2014). Faktor-faktor yang mempengaruhi persepsi wakif tentang wakaf uang. Esensi: Jurnal Bisnis dan Manajemen, 4(1).

Nurbismi, N., \& Ramli, M. R. (2018). Pengaruh Zakat Produktif, Pendapatan, dan Kinerja Amil Terhadap Kemiskinan Mustahik di Kota Banda Aceh. Jurnal EMT KITA, 2(2), 55-61.

Prastiawati, F., \& Satya Darma, E. (2016). Peran Pembiayaan Baitul Maal Wat Tamwil Terhadap Perkembangan Usaha dan Peningkatan Kesejahteraan Anggotanya dari Sektor Mikro Pedagang Pasar Tradisional. Jurnal Akuntansi Dan Investasi, 17(2), 197-208.

Rachman, P., \& Herianingrum, S. (2017). Pemberdayaan Wakaf Tunai Pada Baitul Maal Hidayatullah Di Surabaya Dalam Bidang Pendidikan. Jurnal Ekonomi Syariah Teori dan Terapan, 3(8), 669.

Ryandono, M. N. H., \& Hazami, B. (2016). Peran dan implementasi waqaf dalam peningkatan kesejahteraan masyarakat. Inferensi: Jurnal Penelitian Sosial Keagamaan, 10(1), 239-264.

Wiliasih, R., \& Shadrina, F. (2017). Faktor Dominan Yang Memengaruhi Keputusan Nasabah Untuk Menabung di Bank Syariah, BPRS, dan KSPPS. Nisbah: jurnal perbankan syariah, 3(2), 442-461. 